\title{
Stress-stain state of a vertical steel tank affected by bottom sediments in conditions of extreme temperature differences
}

\author{
R.R. Sultanbekov \\ Postgraduate student, Saint-Petersburg Mining University, Saint-Petersburg, Russian Federation \\ R.D. Terekhin \\ Student, Saint-Petersburg Mining University, Saint-Petersburg, Russian Federation \\ M.N. Nazarova \\ PhD, Associate professor, Saint-Petersburg Mining University, Saint-Petersburg, Russian Federation
}

\begin{abstract}
This article describes the analysis of the stress-strain state of the tank taking into account bottom sediments of oil products and the influence of the temperature of the oil product and the environment using the Ansys software package. Effects that oil product has separately and oil product with bottom sediments have on a stress-stain state are compared. Oil products having different temperatures of $20,30,40,50{ }^{\circ} \mathrm{C}$ are examined in different series. Calculations at various ambient temperatures $\left(-60,-50,-40{ }^{\circ} \mathrm{C} ;-20{ }^{\circ} \mathrm{C} ; 0{ }^{\circ} \mathrm{C} ;+20^{\circ} \mathrm{C}\right.$; $+40{ }^{\circ} \mathrm{C}$ ) are presented in each series. Different densities of oil product and bottom sediment were considered. Based on the analysis of the stress-strain state using finite element modeling on the example of a vertical steel tank, it was shown that the stresses in the zone of the miter weld, as well as in the places of installation of the receiving-distributing branch pipe and the manhole, are maximum. It is in these zones that the influence of bottom sediment and temperature is significant, since they form local elevated stress zones, which increase significantly when the walls are thinned.
\end{abstract}

\section{INTRODUCTION}

The subject of this work is vertical steel tank of the PBC series, and bottom sediments which can appear during normal operation.

Actuality of the work is dictated by absence of scientific research on the theme and by need in increasing reliability, efficiency and safety of oil tank operation.

The study is aimed on testing the following hypothesis: temperature of the bottom sediment affects the stress-stain state of a steel tank; more accurately, the higher change in temperature of a bottom sediment is, the greater stress values are observed in the wall of the tank. This statement is based on the fact that the density of a liquid depends on its temperature. Moreover, temperature stresses appear when the metal wall is heated by bottom heaters of a reservoir. However, it is unclear whether these phenomena can lead to serious consequences, up to reservoir destruction, and is there a significant interplay between temperature changes and the presence of bottom sediments.

The theme of this study is new and is uncovered in previous works. There are a number of studies related to stress-stain study of a steel tank in correlation with cyclic operation loads (Prokopov \& Tkachyova., 2015), in correlation with temperature changes (Kuzeev et al., 2013).

The first work considers the same oil tank series as in the current study, but with a different volume, and uses finite element method. Results show influence of loads on the bottom part of the tank and especially its foundation. The second work shows the stress in the zone of 
a nozzle using the same finite element method. However, none of these studies consider the affect that bottom sediments can have on a stress-stain state of a tank.

The only work on the theme is made by the authors of this work. Authors have been doing research on the theme for quite a long time, and have articles published (Sultanbekov et al., 2019). In this work temperature changes are greater; moreover, environment temperature is also taken into account. The previous work did not take this aspect into consideration.

In this article authors model the stress-stain state of a vertical steel tank in ANSYS software package, figure out the value of stresses in the wall in different temperatures, make conclusion about connection between stress level and sediment temperature.

\section{THEORY AND METHOD}

\subsection{Theoretical background}

Tanks for oil and oil product storage are one of the main technological objects of oil depots and trunk oil pipelines (Sherstobitova et al., 2008). The ecology of the area where tank farms and human safety are located depends on their reliability. Ensuring the required level of reliability of the steel vertical cylindrical tank is carried out at the operation stage. In case of tank accidents, oil products pollute adjacent territories and water basins (Bykova et al., 2019). The economic damage from accidents involving leakage of petroleum products includes not only direct losses, but also the costs of environmental measures to restore the environment, as well as the costs of replenishing the stock of petroleum products.

Modern regulatory documents, (GOST R 52910 - 2008) do not establish the maximum service life of tanks. Tank dismantling is done only according to the results of a diagnostic examination - instrumental and calculated (Kuzeev et al., 2013). The tank is a vertical shell with a bottom; however, the presence of geometric features significantly changes the symmetry of the structure, the distribution of stresses and strains in local zones, which is difficult to take into account when performing analytical calculations.

Thanks to the use of software systems for finite element calculations, such as Ansys, it becomes possible to determine the most dangerous zones and predict the stress-stain state (SSS) during operation, taking into account additional factors. One of such is bottom sediment, which is formed during storage and mixing of oil products (Sultanbekov \& Nazarova, 2019). Especially active sedimentation is observed when different types of residual oil products are mixed due to their incompatibility (Mitusova et al., 2018). Sedimentation occurs due to imbalance and instability of fuels, when the amount of aromatic hydrocarbons decreases, so the proportion of paraffin and asphaltenes in the mixture increases (Kondrasheva et al., 2019). Cases of "incompatibility" during the mixing of petroleum products are associated with the emergence of strong intermolecular interactions caused by changes in the structural group composition and the mutual ratio of the concentrations of high molecular weight compounds of petroleum products (Karimov \& Mastobaev, 2012), which leads to the formation of molecular associates, bulk colloidal particles of various shapes and structures (Kondrasheva et al., 2018). The problem of "incompatibility" of oil products is extremely urgent, since due to the precipitation of sediment on the tanks during operation, the useful volume decreases and the need to clean the tanks arises, and when mixing fuels because of the "incompatibility", the quality of the whole product deteriorates in the first place, the subsequent use of which increases the risk of equipment wear (ISO 8217, 2017).

When there is a big temperature difference, especially in zones of extremely low temperatures, the problem of reservoir operation is quite important (YUhtorov et al., 2018). Such conditions can be found in some northern regions, in the Arctic zone. Tank's wall metal is exposed to greater loads, and this fact should be taken into consideration during tank design to ensure its safe and reliable operation (Bondarev et al., 2017). 


\subsection{Method}

To determine the effect of bottom sediment, mainly consisting of asphaltene-tar paraffin deposits, on SSS diagram, we consider vertical steel tank PBC-20000, which stores a mixture of residual fuels of the RMK-700 grade with a density of $958 \mathrm{~kg} / \mathrm{m} 3$ at $15{ }^{\circ} \mathrm{C}$ and has a viscosity of $550 \mathrm{sSt}$ at $50{ }^{\circ} \mathrm{C}$. Liquid surface height is 12 meters, the material of the tank is Steel 3. There is a fixed roof, the weight with the equipment installed on it is 10,000 N. Laboratory tests of viscosity were performed using a Stabinger SVM 3000 laboratory instrument, and Anton Paar DMA 4100 M equipment used to measure density. The results are shown in Table 1.

The reservoir model was created and the tank SSS calculations were performed in the Ansys software package, taking into account the stored residual fuel and total sediments at a temperature of $20^{\circ} \mathrm{C}$ (Figure 1).

Table 1. Density of the residual fuel and total sediment depending on the measurement temperature.

\begin{tabular}{lll}
\hline Temperature, ${ }^{\circ} \mathrm{C}$ & Total sediment, $\mathrm{kg} / \mathrm{m} 3$ & Residual fuels RMK-700, $\mathrm{kg} / \mathrm{m} 3$ \\
\hline 15 & 1090.0 & 958.0 \\
20 & 1087.2 & 954.8 \\
25 & 1084.4 & 951.6 \\
30 & 1081.5 & 948.4 \\
35 & 1078.7 & 945.1 \\
40 & 1075.9 & 941.9 \\
45 & 1073.0 & 938.7 \\
50 & 1070.2 & 935.4 \\
55 & 1067.4 & 932.2 \\
60 & 1064.5 & 928.9 \\
65 & 1061.6 & 925.7 \\
70 & 1058.8 & 922.4 \\
\hline
\end{tabular}

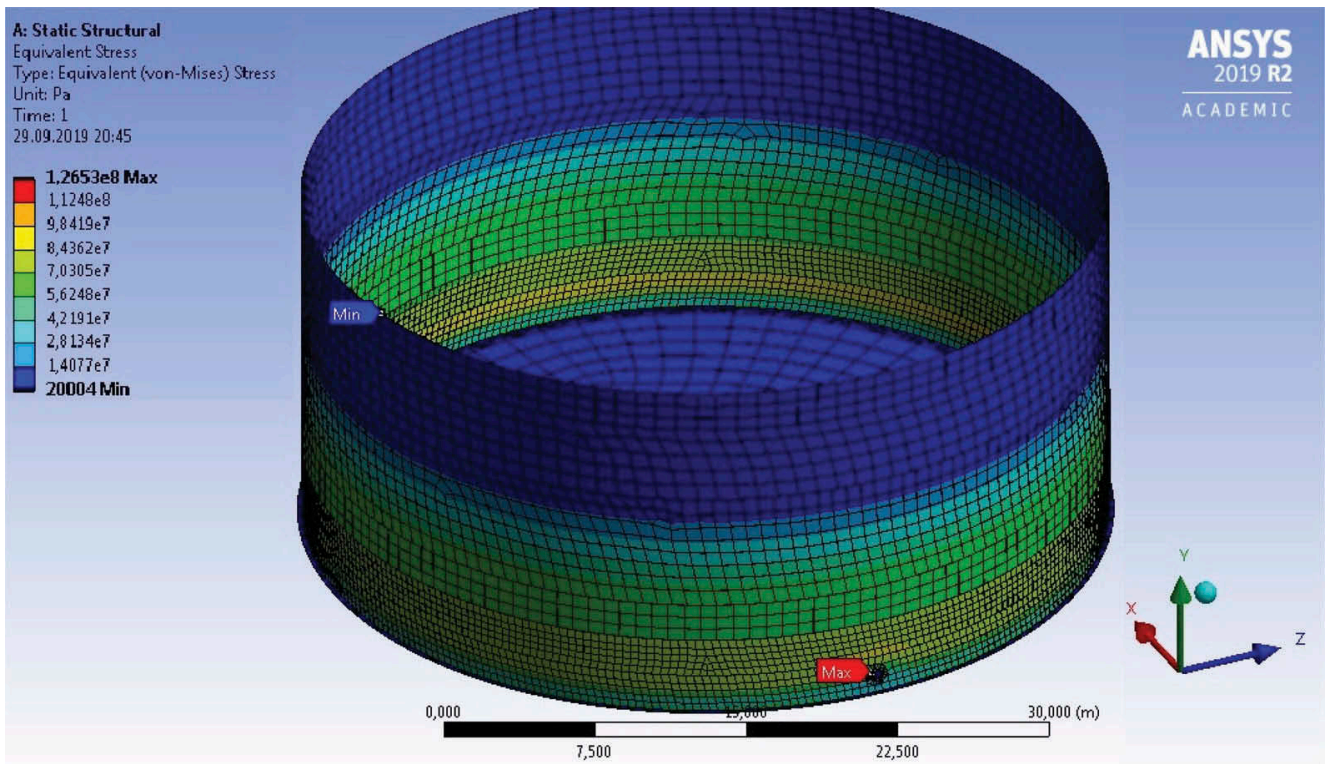

Figure 1. SSS of a reservoir without bottom sediment, $20^{\circ} \mathrm{C}$. 


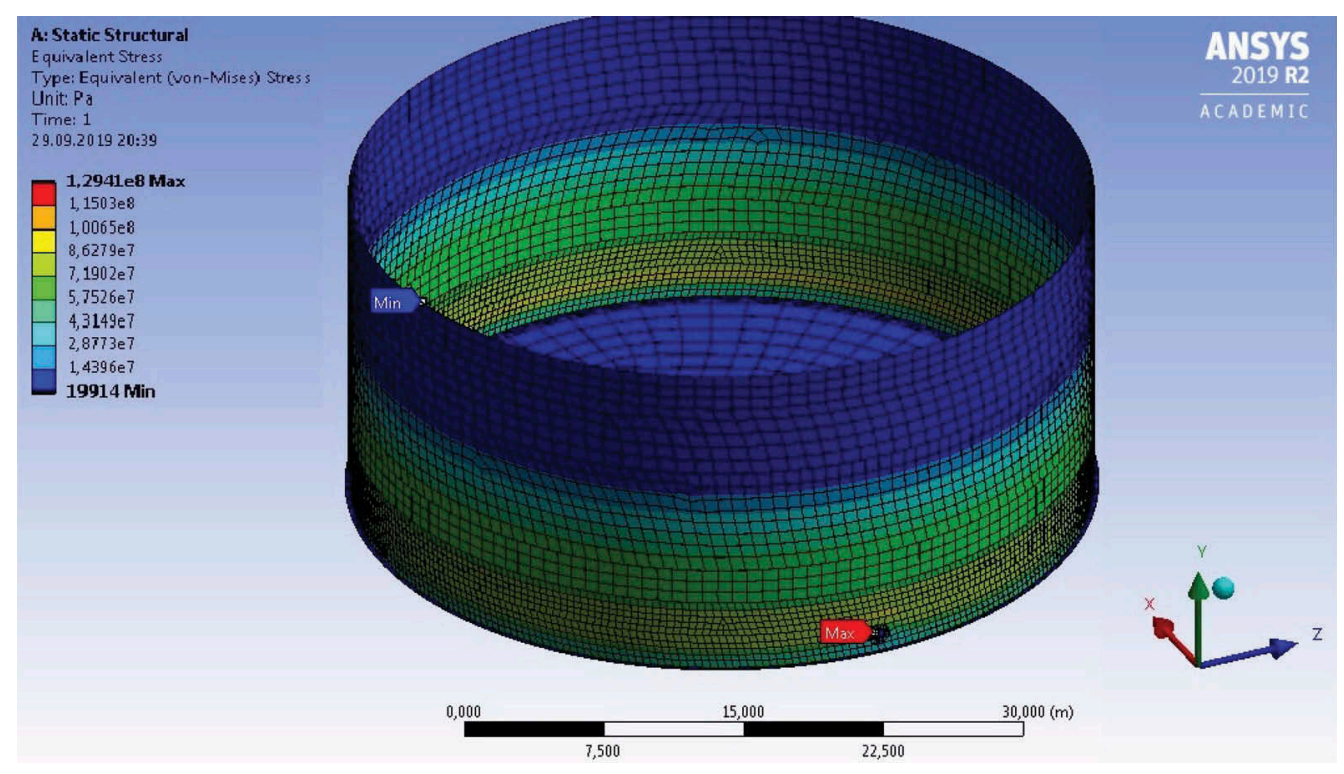

Figure 2. SSS of a reservoir, 1,3 meter of bottom sediment, $20^{\circ} \mathrm{C}$.

In the absence of sediments, the maximum stresses of $126 \mathrm{MPa}$ are observed in the zone of the masonry weld, as well as in the places of installation of the dispensing nozzle and manhole.

Another calculation is made with bottom sediment with a height of 1.3 meters. The density of sediments is $1090 \mathrm{~kg} / \mathrm{m}^{3}$ at $15^{\circ} \mathrm{C}$. (Figure 2).

Attention should be paid to an increase in the maximum stresses created by the liquid column. Unaccounted stress in the metal can lead to negative consequences, especially under bad circumstances. Especially when you consider that the tank is loaded cyclically, and metal failure may occur earlier than anticipated. Especially when you consider that the tank is loaded cyclically, and metal failure may occur earlier than anticipated.

The ambient temperature changes, so does the magnitude of the stresses in the tank wall. This is due to the thermal expansion of the metal. Bottom sediments also affect the stress experienced on the tank wall. So, with a large temperature difference, the maximum stress in the metal can exceed the yield strength, which leads to the destruction of the tank.

Several series are to be calculated. Let the fluid in the tank be heated, its density and temperature are constant during one series. Totally there are four series for each temperature of the stored product $-20,30,40,50{ }^{\circ} \mathrm{C}$. Calculations for different ambient temperatures $(-60$, $-40,-20,0,20,40^{\circ} \mathrm{C}$ ) are made in one series.

\subsection{Product's temperature is $50^{\circ} \mathrm{C}$.}

Results are shown on Figure 3. Calculation is present for six different ambient temperatures and the same product temperature, which is constant and is $50{ }^{\circ} \mathrm{C}$.

As expected, maximum stress values are obtained with greater temperature difference, and are located in the zones of nozzle and manhole. As the temperature gets higher, stress is lowered at first and gets bigger then, but its distribution is almost the same. Points of max and min values in these cases differ because of low mesh resolution due to free license limitations. Results of calculations are in the Table 2. 


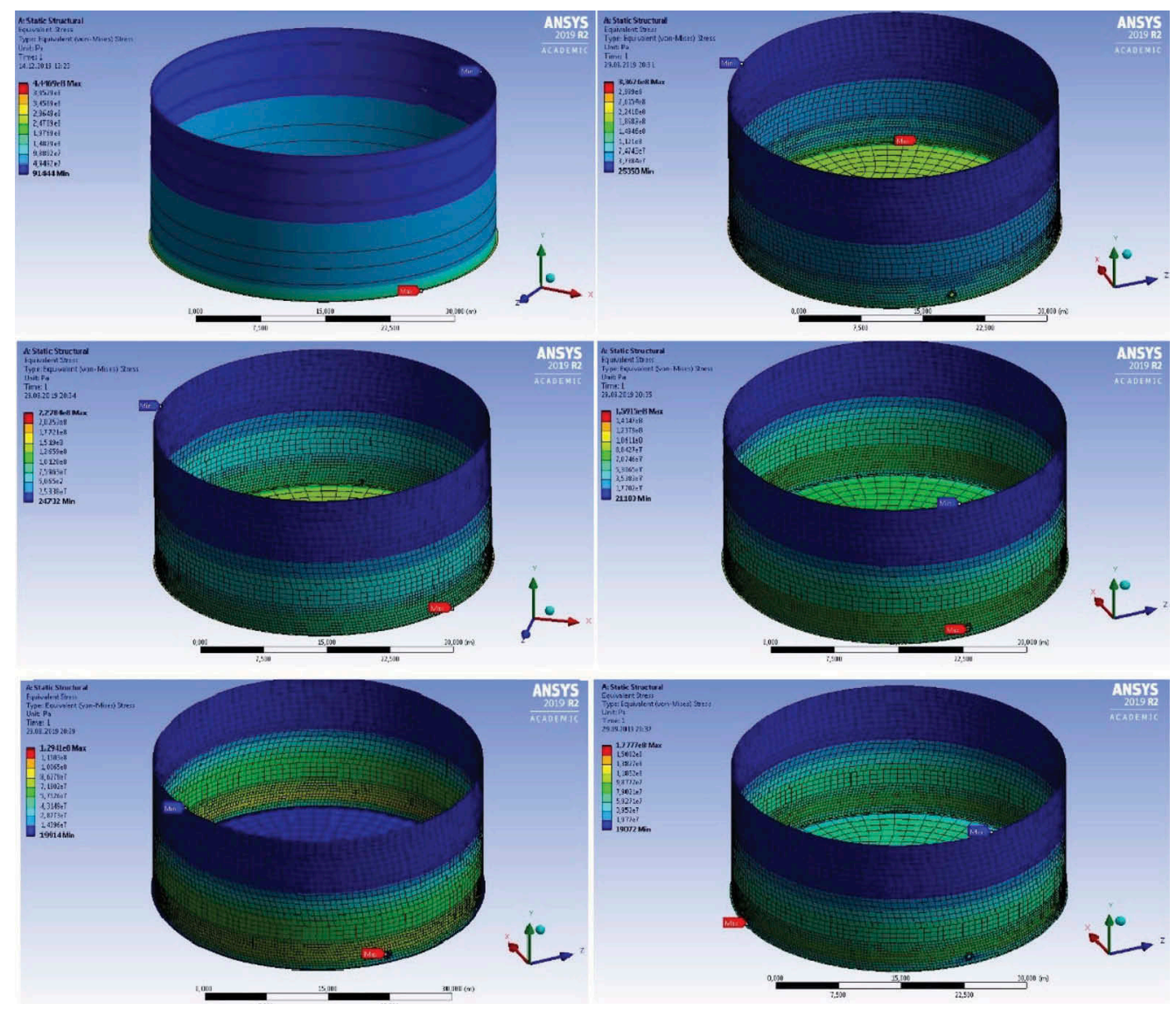

Figure 3. SSS of a reservoir, 1.3 meter of bottom sediment, different ambient temperatures, product at $50{ }^{\circ} \mathrm{C}$.

Table 2. Stress depending on the temperature, product at $50^{\circ} \mathrm{C}$.

\begin{tabular}{ll}
\hline Ambient temperature, ${ }^{\circ} \mathrm{C}$ & Maximum stress in a wall, Mpa \\
\hline-60 & 444 \\
-40 & 336 \\
-20 & 227 \\
0 & 159 \\
20 & 129 \\
40 & 177 \\
\hline
\end{tabular}

\subsection{Series representing product at $40^{\circ} \mathrm{C}$}

As well as in the previous set of calculations, product temperature is constant while ambient temperature is changing. SSS remains almost the same while values change dramatically (Figure 4).

Slight increase in stress due to increased densities of product and sediment is worth mentioning.

Results are shown in the Table 3. Some values representing stress in nozzle or manhole (the bigger one) are shown separately. Theoretically such different values are caused 


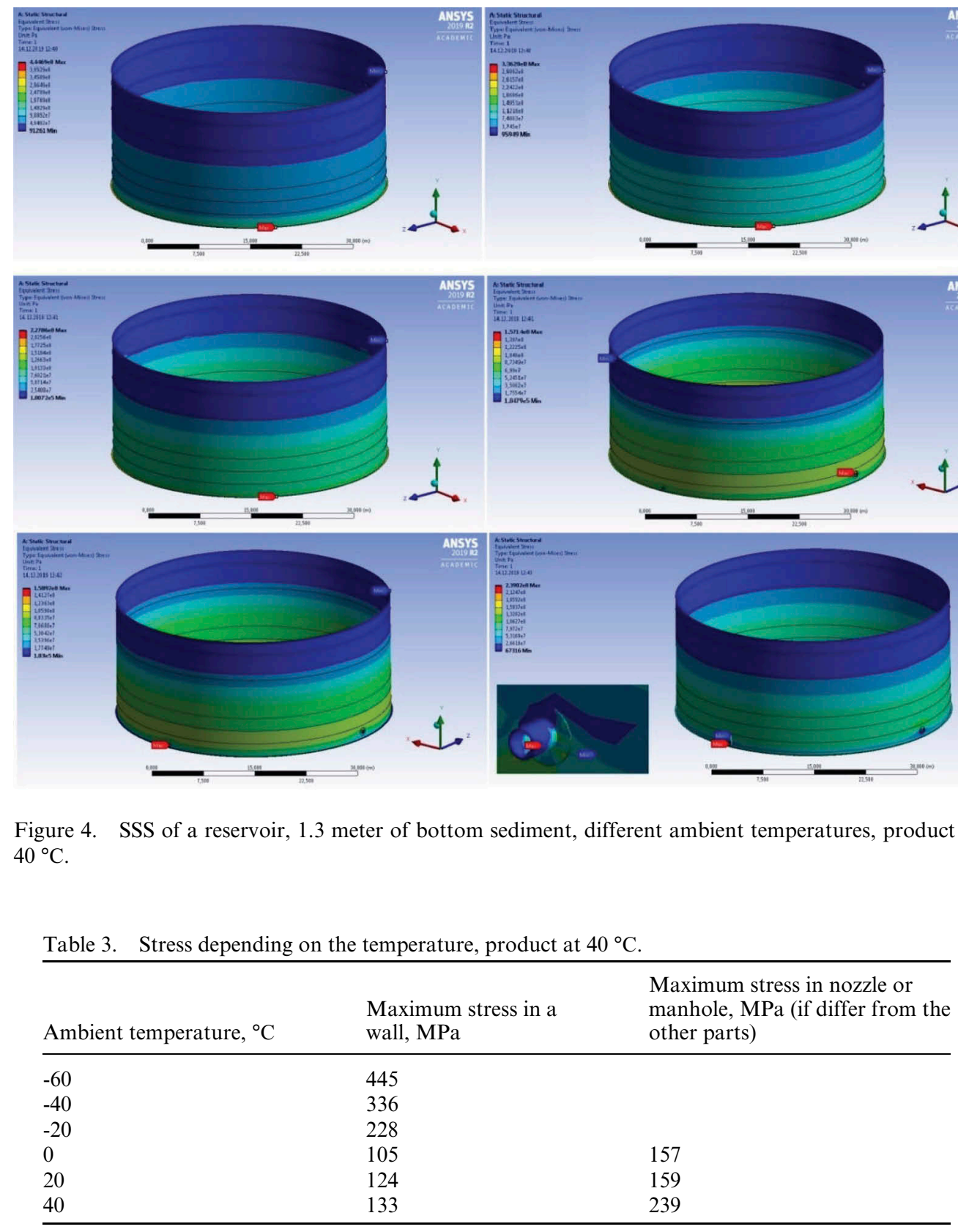

by low-resolution mesh rather than actual load on the part. It can be understood while closely examining the results: only one mesh node has such great values.

\subsection{Series representing product at $30^{\circ} \mathrm{C}$}

The same as above. Calculation results are shown on Table 4.

Stress measured in manhole and nozzle zones doesn't necessarily represent actual stresses in a real reservoir. Calculation results are shown in Table 4. 
Table 4. Stress depending on the temperature, product at $30^{\circ} \mathrm{C}$.

\begin{tabular}{lll}
\hline Ambient temperature, ${ }^{\circ} \mathrm{C}$ & $\begin{array}{l}\text { Maximum stress in a } \\
\text { wall, MPa }\end{array}$ & $\begin{array}{l}\text { Maximum stress in nozzle or manhole, } \\
\text { MPa (if differ from the other parts) }\end{array}$ \\
\hline-60 & 446 & \\
-40 & 337 & \\
-20 & 229 & 158 \\
0 & 106 & 160 \\
20 & 125 & 240 \\
40 & 133 & \\
\hline
\end{tabular}

Table 5. Stress depending on the temperature, product at $20^{\circ} \mathrm{C}$.

\begin{tabular}{lll}
\hline Ambient temperature, ${ }^{\circ} \mathrm{C}$ & $\begin{array}{l}\text { Maximum stress in a } \\
\text { wall, MPa }\end{array}$ & $\begin{array}{l}\text { Maximum stress in nozzle or manhole, } \\
\text { MPa (if differ from the other parts) }\end{array}$ \\
\hline-60 & 447 & \\
-40 & 337 & \\
-20 & 229 & 159 \\
0 & 107 & 162 \\
20 & 126 & 242 \\
40 & 135 & \\
\hline
\end{tabular}

\subsection{Series at $20^{\circ} \mathrm{C}$}

In previous cases the product was heated. Now let's consider the situation without heating. Product density reaches its maximum, so the highest values of stress are expected.

As expected, stresses are mostly to the thermal expansion of wall metal. The most dangerous points are again the nozzle and the manhole. Stress values change while the distribution remains the same. Results are shown in Table 5.

\section{CONCLUSIONS}

As a result of the analysis of the stress-strain state of the tank, taking into account the operational loads of the reservoir models, it was established that the stress in the casing increases during the operation of the reservoir.

Analysis of SSS using finite element methods showed that with active sedimentation and an increase in the temperature of the stored product, an increase and redistribution of stresses occurs in the lower zone. Also, calculations of the influence of ambient temperature and bottom sediment on SSS showed the highest stresses in the lower zone at the most negative values, namely $-60 \mathrm{C}$. As a result, stress concentration zones arise that are located directly in the zone of the weld seam and in the places of installation of the receiving-distributing branch pipe and manhole, which are not taken into account when calculating by standard methods.

\section{REFERENCES}

Bondarev E., Rozhin I., and Argunova K. 2017 Features of mathematical modeling of natural gas production and transportation systems in the Arctic zone of Russia. Journal of Mining Institute, 228 (6), 705. DOI: http://dx.doi.org/10.25515/pmi.2017.6.605.

Bykova M.V., Pashkevich M.A., Matveeva V.A., Sverchkov I.P. 2019. Assessment and abatement of the soil oil-contamination level in industrial areas. In: Litvinenko V. (ed.), Topical Issues of Rational Use 
of Natural Resources - Proceedings of the International Forum-Contest of Young Researchers, pp. 347-359.

GOST R 52910-2008. Rezervuary vertikal'nye cilindricheskie stal'nye dlja nefti i nefteproduktov. Obshhie tehnicheskie uslovija. M.: Standartinform. 56 c. [in Russian].

ISO 8217 Fuel Standar. - 2017. - URLhttps://https://www.wfscorp.com/sites/default/files/ISO-8217-2017Tables-1-and-2-1-1.pdf (date of the application10.01.2019).

Karimov R M, Mastobaev B N. 2012. Vliyanie soderzhaniya parafinov, smol i asfal'tenov na tovarnye kachestva neftej//Bashkirskij himicheskij zhurnal.-Tom 19.

Kondrasheva N. K., Eremeeva A. M., \& Nelkenbaum K. S. 2018. Development of domestic technologies of produsing high quality clean diesel fuel. Izvestiya vysshikh uchebnykh zavedenii Khimiya Khimicheskaya Tekhnologiya, 61(9-10), 76-82. https://doi.org/10.6060/ivkkt.20186109-10.5651.

Kondrasheva N. K., Eremeeva A. M., Nelkenbaum K. S., Baulin O. A. \& Dubovikov O. A. 2019. Development of environmentally friendly diesel fuel, Petroleum Science and Technology, 37:12, 1478-1484, DOI: $10.1080 / 10916466.2019 .1594285$.

Kondrasheva N K, Rudko V A, Kondrashev D O, Konoplin R R, Smyshlyaeva K I, and Shakleina V S. 2018. Functional influence of depressor and depressor-dispersant additives on marine fuels and their distillates components. Petroleum Science and Technology 36 (24), 2099-2105. DOI: 10.1080/ 10916466.2018.1533858.

Kondrasheva N K, Rudko V A, Kondrashev D O, Shakleina V S, Smyshlyaeva K I, Konoplin R R, Shaidulina A A, Ivkin A S, Derkunskii I O, Dubovikov O A. 2019. Application of a Ternary Phase Diagram to Describe the Stability of Residual Marine Fuel /// Energy \& Fuels. Vol. 33, № 5. P. 4671-4675.

Kuzeev I.R., Tlyasheva R.R. and others. 2013. Technique of definition the stress-strain state of the steel cylindrical tank. FSBEI HPE "Ufa state petroleum technological university", Ufa, Russian Federation. - №4 - pp. 339-347. http://ogbus.ru/article/view/metodika-opredeleniya-napryazhenno-deformir ovannogo-sostoyaniya-stalnogo-cilindricheskogo-rezervuara.

Mitusova T N, Kondrasheva N K, Lobashova M M, Ershov M A, and Rudko V A. 2017. Influence of dispersing additives and blend composition on stability of marine high-viscosity fuels. Journal of Mining Institute 228, 722-725. DOI: 10.25515/PMI.2017.6.722.

Mitusova T N, Kondrasheva N K, Lobashova M M, Ershov M A, and Rudko V A and Titarenko M A. 2018. Determination and Improvement of Stability of High-Viscosity Marine Fuels. Chemistry and Technology of Fuels and Oils 53 (6), 842-845. DOI: 10.1007/s10553-018-0870-.

Prokopov A.Y., Tkachyova K.E. 2015. A study of stress-strain state of foundation of vertical vessel subject to dynamic operating loads. Inzhenerniy vestnik Duna, №3. https://ivdon.ru/ru/magazine/archive/ n3y2015/3200 [in Russian].

Sherstobitova R T, et al. 2008. Povyshenie bezopasnosti RVS, dlitel'no jekspluatiruemyh v uslovijah nizkih temperature, Ufa: UGNTU, $131 \mathrm{c}$. [in Russian].

Sultanbekov R. R., Nazarova M. N. 2019. Determination of compatibility of petroleum products when mixed in tanks. EAGE., Tyumen, DOI: 10.3997/2214-4609.201900614. Available at: http://earthdoc. eage.org/publication/publicationdetails/?publication=96369 (Accessed 30 March 2019).

Sultanbekov R.R., Terekhin R.D., Nazarova M.N. 2019. Effect of temperature fields and bottom sediments of oil products on the stress-strain state of the design of a vertical steel tank. Journal of Physics Conference Series, 1431:012055, DOI: 10.1088/1742-6596/1431/1/012055.

YUhtorov V. N., Korol'chenko I. A., Ulanin S E., Sokolov D. N. 2018. Obosnovanie sposoba prognozirovaniya sohranyaemosti kachestva nefteproduktov pri dlitel'nom hranenii (Substantiation of method for forecasting of preserved quality of oil products during long storage).//Mir nefteproduktov. Vestnik neftyanyh kompanij. - №3. - S. 20-27 [in Russian]. 